\title{
Congress goes easy on science-so far
}

A KEY subcommittee of the US House of Representatives last week recommended that $\$ 19$ million be cut from the budget request for the National Science Foundation which had been submitted by President Carter. Although this represents a reduction of almost $2 \%$ in the $\$ 1,006$ million request submitted. It is considerably less than the $\$ 44$ million reduction which the same subcommittee wanted made in the NSF's budget last year.

The subcommittee's recommendations, which have to be accepted by the full committee of Appropriations before being debated on the floor of the House, would delete $\$ 10$ million from the agency's basic research programmes out of a requested total of $\$ 793.3$ million, $\$ 3$ million out of the $\$ 62.4$ million requested for the applied science and research applications programmes, and $\$ 3$ million out of programme management.

\section{Senate committee kills fast breeder}

A NEW political confrontation over the future of the liquid metal fast breeder reactor project at Clinch River in Tennessee seems certain after the Senate Energy and Natural Resources Committee last week accepted a proposal from Senator Dale Bumpers of Arkansas to kill the $\$ 2.6$ billion project. The House Science and Technology Committee has already voted to continue.

President Carter has consistently been opposed to the plan, initially on the grounds that the use of plutonium in fast breeders increases the chances of nuclear proliferation. More recently, the President has claimed that the Clinch River design was obsolete after new advances in technology, and that with a slowing down in growth of energy demand, the need for fast breeders is not so urgent.

\section{Technical aid restored to UN bodies}

THE US Senate voted last week to repeal a decision, taken in the heat of the closing hours of the 95th Congress last autumn, which effectively cut off all US contributions to bodies in the United Nations system.

The earlier decision took the form of an amendment, proposed by Senator Jesse Helms of North Carolina, which specified that none of the funds which the US contributes to bodies such as the World Health Organisation and the Food and Agricultural Organisation could be used for the purpose of "technical assistance".

The UN bodies subsequently told the US State Department that it could not
The subcommittee made no mention of the ceiling which Congress placed on salaries of NSF grant-holders last year, leading some to speculate that the ceiling might be lifted during conference with the Senate. However, neither did it add any extra money for research on earthquake hazards, for which the House last month authorised spending to be increased from $\$ 18.3$ million to $\$ 22.8$ million.

NSF officials were relieved that the cuts were not greater (a move to make an additional $\$ 12$ million cut is said to have been headed off in the subcommittee meeting). However, the real tests will come in the middle of next month when the NSF request is debated both on the floor of the House -where the Appropriations Bill has already been cut back by $\$ 14$ millionand in the Senate Appropriations Subcommittee chaired by Senator William Proxmire.

The General Accounting Office, however, which carries out studies of particular issues for the Congress, disagrees with the President. In a report published earlier this month, the GAO stated that the Clinch River project would be a "logical and prudent step".

In pledging its support for the project, the House Committee added $\$ 184$ million to the authorisation request for the Department of Energy so that the project could proceed. Senator Bumpers' proposal, which has been accepted by the Senate Energy Committee, is to terminate the breeder project by 1 October, but to authorise a design study for a larger breeder test plant. "Clinch River is dead and the sooner we admit it, the more the American people will applaud us for doing it," Senator Bumpers said.

accept contributions under those conditions. Last week, however, in passing the Foreign Relations Authorisations Act for 1980, the Senate in effect repealed the Helms Amendment, following a similar move in the House of Representatives.

The Senate also defeated, by 54 votes to 35 , a further amendment from Senator Helms which would have revived the issue by refusing to include money for technical assistance in the mandatory contributions which the US pays to the UN bodies. Senator Helms said it was a matter of whether the Senate wished to impose an 'International Tax' on Americans.

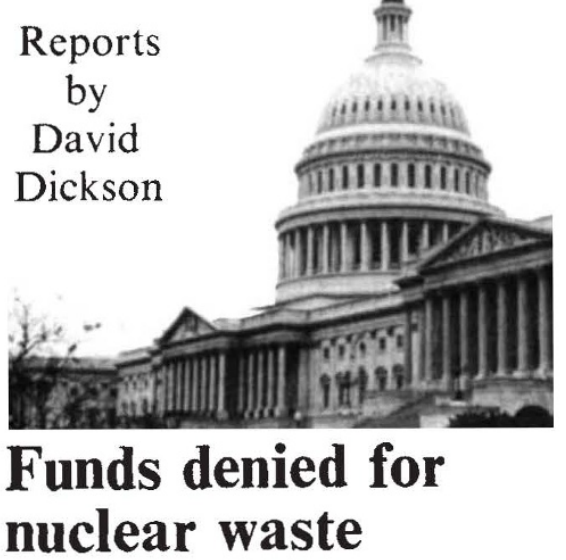

THE House Armed Services Committee has voted to cut off all funds for an experimental project to store nuclear waste in salt caverns near Carlsbad, New Mexico.

The project, known as a waste isolation pilot plant (WIPP) has been under development by the Department of Energy for some time. The site was chosen in 1976, and if permission to build the plant is granted, the site could be ready to receive both transuranic wastes from the defence programme and commercial waste from nuclear reactors within a few years.

The scheme has generated intense controversy in New Mexico. Supporters say the WIPP facility would bring new jobs and extra income to the area. Opponents claim it would restrict access to other valuable resources, such as potash, and also point to doubts over the suitability of salt as a disposal medium.

The House Armed Services Committee voted against further funding for the WIPP facility not on environmental or scientific grounds, but because it felt that a plant initially intended for defence wastes should not also be used for the disposal of commercial wastes. Meanwhile, the Senate Armed Services Committee has agreed to let funding for the project stand in the Department of Energy's budget request, but on the understanding that no commercial spent fuel should be stored at the WIPP site.

The outcome will depend on what happens in floor debates and during the conference between the House and the Senate. Another factor will be the President's announcement soon on federal waste disposal, following a report on nuclear waste management prepared last year by an interagency review group.

Meanwhile, the Senate and the New York State Assembly announced last week a curb on the amount of nuclear waste that can be stored in the state's West Valley facility, which has been closed since 1972. 